\title{
DINOL wt Allele
}

National Cancer Institute

\section{Source}

National Cancer Institute. DINOL wt Allele. NCI Thesaurus. Code C132162.

Human DINOL wild-type allele is located in the vicinity of $6 \mathrm{p} 21.2$ and is approximately $1 \mathrm{~kb}$ in length. This allele, which encodes damage induced long noncoding RNA, plays a role in stabilization of cellular tumor antigen p53. 